\title{
Factors related to orthodontic treatment time in adult patients
}

\author{
Ana Camila Esteves de Oliveira Melo1, Lilianne Oliveira Thiers Carneiro1, Luana Farias Pontes², Rodolpho Lobão Cecim³, \\ José Nazareno Rufino de Mattos ${ }^{4}$, David Normando ${ }^{5}$
}

Introduction: The length of time that it takes an orthodontist to treat adult patients varies widely. Objective: The aim of this study was to investigate how different variables influence treatment time. Methods: Seventy clinical case reports of successfully treated adult patients were examined. The patients were selected from 4,723 records held by three experienced orthodontists. The influence exerted by the following variables on treatment time was assessed: age, sex, facial pattern, severity of malocclusion (measured by the PAR index), sagittal relationship of canines, type of brackets (ceramic or metal), tooth extractions, missed appointments and orthodontic appliance issues/breakages, the latter being the dependent variable. Assessment was performed by multiple linear regression analysis, followed by the stepwise method with $\mathrm{P}<0.05$. Results: The number of times a patient missed their appointment (no-show) $\left(\mathrm{R}^{2}=14.4 \%, \mathrm{p}<0.0001\right)$ and the number of appliance issues/breakages $\left(\mathrm{R}^{2}=29.71 \%, \mathrm{p}=0.0037\right)$ significantly affected variability in treatment time, and these two variables together can predict $43.75 \%\left(\mathrm{R}^{2}\right.$ total) of the overall variability in treatment time. Other factors, such as canine relationship at the beginning of treatment, bracket type (metal or ceramic), tooth extractions, age at start of treatment, severity of the initial malocclusion, sex and facial pattern had no significant bearing on treatment time. Conclusions: The duration of orthodontic treatment in adults, when performed by experienced orthodontists, is mainly influenced by factors related to patient compliance. However, several factors which were not included in this study may contribute to variability in orthodontic treatment time.

Keywords: Adult. Time factors. Orthodontics.

Introdução: o tratamento ortodôntico de pacientes adultos apresenta grande variabilidade no tempo necessário para sua realização. Objetivo: o objetivo desse trabalho foi investigar a influência de diversas variáveis sobre o tempo de tratamento. Métodos: foram examinados 70 casos clínicos, de pacientes adultos, com bom resultado final, coletados em clínicas de três ortodontistas experientes, cujo acervo total inicial era de 4.723 prontuários. A influência das variáveis idade, sexo, padrão facial, severidade inicial da má oclusão (medida por meio do índice PAR), relação sagital de caninos, tipo de braquetes (estético ou metálico), exodontias, faltas às consultas e "quebras" de aparelho, sobre o tempo de tratamento (variável dependente), foram avaliadas por meio da análise de regressão linear múltipla, seguida do método Stepwise, com p < 0,05. Resultados: a quantidade de faltas $\left(\mathrm{R}^{2}=14,04 \%, \mathrm{p}<0,0001\right)$ e o número de "quebras" do aparelho $\left(\mathrm{R}^{2}=29,71 \%\right.$, $\mathrm{p}=0,0037)$ tiveram influência significativa na variação do tempo de tratamento, sendo essas duas variáveis juntas capazes de prever $43,75 \%$ ( $\mathrm{R}^{2}$ total) da variação no tempo de tratamento. Outros fatores, como a relação de caninos ao início do tratamento, o tipo de braquete usado (metálico ou cerâmico), exodontias, a idade ao início do tratamento, a severidade inicial da má oclusão, o sexo do paciente e o padrão facial não tiveram influência significativa sobre o tempo de tratamento. Conclusão: a duração do tratamento ortodôntico em adultos, quando realizado por ortodontistas experientes, sofre influência, principalmente, de fatores associados à colaboração do próprio paciente. Entretanto, diversos fatores não incluídos nesse estudo podem contribuir para a variação na duração do tratamento ortodôntico.

Palavras-chave: Adulto. Fatores de tempo. Ortodontia.

${ }^{1}$ Specialist in Orthodontics, $\mathrm{ABO} / \mathrm{PA}$.

${ }^{2}$ Postgraduate student in Orthodontics, Federal University of Pará (UFPA).

${ }^{3}$ Specialist in Orthodontics, ABO/PA. MSc in Oral Pathology, UFPA.

${ }^{4}$ Professor, Department of Orthodontics, ABO/PA. MSc in Dentistry, UFPA.

${ }^{5}$ Associate Professor, Department of Orthodontics, UFPA.

" The authors report no commercial, proprietary or financial interest in the products or companies described in this article.
How to cite this article: Melo ACEO, Carneiro LOT, Pontes LF, Cecim RL, Mattos JNR, Normando D. Factors related to orthodontic treatment time in adult patients. Dental Press J Orthod. 2013 Sept-Oct;18(5):59-63.

Submitted: July 25, 2013 - Revised and accepted: August 16, 2013

Contact address: Ana Camila Esteves de Oliveira Melo Rua Jerônimo Pimentel, 117 - B. Umarizal - Belém/PA, Brazil CEP 66055-000 - E-mail: millamelo18@hotmail.com 


\section{INTRODUCTION}

In today's society, the quest for esthetic perfection is no longer just an aspiration of the youth. As a result, there is an increasing number of adult patients who seek orthodontic treatment to improve not only function but appearance as well. ${ }^{1,2}$

Among the key factors that affect patients and serve to characterize adult vs. young patients are the absence of active growth, higher occurrence of dental mutilation and periodontal involvement. ${ }^{2,3}$ However, the time required for treatment is a major concern of adult patients. Thus, orthodontists must be prepared to provide treatment that meets the specific needs of such patients.

Numerous studies have investigated variables that could influence treatment time in adolescents and adults. Among these factors are aging, ${ }^{3-7}$ sex, ${ }^{4,5,8,9}$ the use of ceramic vs. metal brackets,${ }^{4}$ molar relationship at the beginning of treatment, ${ }^{9,10,11}$ initial severity of the malocclusion, ${ }^{5-8,11-15}$ tooth extractions, ${ }^{4,5,6,8,9,10,15-24}$ number of missed appointments, ${ }^{4-7,18,21}$ issues with the orthodontic appliance (breakages), ${ }^{4-7,9,21}$ patients' oral hygiene, ${ }^{4,8,9,19}$ the orthodontist's experience, ${ }^{15}$ whether or not treatment was performed in a public vs. private facility, ${ }^{5}$ and the patients' noncompliance in the use of intraoral elastics. ${ }^{4,9}$

These studies show conflicting results for one and the same variable analyzed. Moreover, some studies indicate that extractions may lengthen treatment time, compared to non-extraction therapy. $5,6,8,9,15,16,18-21,23,24$ These results, however, are not unanimous. $.^{14,10,17,22} \mathrm{An}-$ other factor that yields conflicting results in the literature is initial severity of the malocclusion. While some authors confirm its effects on treatment time, ${ }^{5,8,11,12,14,15}$ others reject it. ${ }^{6,7,13}$ Molar relationship also exhibits outcome variability as it may, ${ }^{9,11}$ or may not ${ }^{10}$ be associated with the duration of treatment.

Despite the disagreement regarding which variables exert a significant influence on orthodontic treatment time, no study has hitherto been published in the literature focusing on adult patients. The aim of this work was to investigate the influence exerted by different variables on the duration of treatment in adult patients.

\section{MATERIAL AND METHODS}

The records of 4,723 patients treated by three orthodontists with a professional experience of over 20 years were examined. Exclusion criteria included patients under
18 years with incomplete records, patients with more than one tooth missing per quadrant, patients previously treated by orthognathic surgery, syndromic and cleft patients, Class III malocclusion, retreatment cases, and patients who missed appointments for more than six months in a row or alternately. Thus, 123 adult patients were selected. After analyzing the quality of treatment after it was completed, 53 cases were excluded. The final sample consisted of 70 adult patients whose inclusion criteria were: patients aged 18 to 66 years, 48 females and 22 males, Angle Class I or II malocclusions as assessed based on canine relationship.

Treatment time in months was the main variable analyzed. The following predictor variables were observed at baseline $\left(\mathrm{T}_{0}\right)$ and analyzed: Sagittal canine relationship, planned extractions, sex, age, facial pattern, severity of malocclusion, type of brackets (ceramic or metal), missed appointments and appliance issues.

Table 1 shows a summary of nominal variables analyzed in the study.

Severity at the start of treatment was examined by the PAR index, and measured with a universal caliper (Mitutoyo, Brazil, model/code 530-102).

Intraexaminer error was evaluated by performing new measurements and calculating a new PAR index for the models of all selected patients. The first and second measurements were performed with a time interval of 14 days. Dahlberg's formula was applied to estimate random error while systematic error was examined by intraclass correlation.

Initially a correlation matrix was applied in order to examine which predictor variable could be asso-

Table 1 - Summary of nominal variables included in the study

\begin{tabular}{|c|c|c|}
\hline & $\mathbf{n}$ & $\%$ \\
\hline Female & 48 & 68.57 \\
\hline Male & 22 & 31.43 \\
\hline Class I & 33 & 47.14 \\
\hline Class II & 37 & 52.86 \\
\hline Metal brackets & 51 & 72.86 \\
\hline Ceramic brackets & 19 & 27.14 \\
\hline Mesofacial pattern & 35 & 50.00 \\
\hline Brachyfacial pattern & 15 & 21.43 \\
\hline Dolichofacial pattern & 20 & 28.57 \\
\hline
\end{tabular}


ciated with treatment time. Variables with significant correlations were included in the multiple linear regression analysis, which was complemented by linear stepwise regression.

Statistical analysis were performed by BioEstat 5.3 software (Mamirauá Institute, Belém, Pará state, Brazil). All tests were applied adopting a significance level of 5\%.

\section{RESULTS}

Total mean treatment time was 32.2 months, and mean age at start of treatment was 27.7 years. The average number of appliance issues and months of missed appointments was about 3 , and the mean number of extractions was 0.75 . Systematic error analysis revealed excellent repeatability $\left(\mathrm{R}^{2}=0.9662\right)$ of the PAR index at $\mathrm{T}_{0}($ mean $=14.06)$, associated with a small magnitude random error (Table 2).

Correlation analysis revealed that the variables "number of appliance issues", "missed appointments (number of months)", "PAR index at $\mathrm{T}_{0}$ " and "type of brackets (metal or ceramic)" were somewhat correlated $(p<0.05)$ with the main variable, i.e., "length of treatment." The variable "number of extractions" was also included due to its p-value (0.0543), which was very close to the value established for the level of significance (Table 3).

Multiple linear regression revealed that among the five dependent variables included in the analysis, only "number of issues/breakages" and "months of missed appointments (no-shows)" proved significant $(p<0.001)$. Stepwise regression showed that together the five variables exerted an influence of $54.33 \%$ on treatment time variability, with "number of appliance issues/breakages" showing an influence of 29.71\% ( $p<0.001)$, and "missed appointments" an influence of $14.04 \%$ ( $\mathrm{p}<0.001)$, followed by the PAR index at $\mathrm{T}_{0}$, with an influence of $6.51 \%$, "number of extractions" (2.42\%) and finally "type of brackets" exhibited an influence of $1.65 \%$ on the total treatment time.

Table 2 - Descriptive analysis of numerical variables.

\begin{tabular}{|c|c|c|c|c|}
\hline \multirow{2}{*}{ Variables $(n=70)$} & \multicolumn{2}{|c|}{ Descriptive statistics } & \multicolumn{2}{|c|}{ Error Analysis } \\
\hline & Mean & SD & Random & Systematic \\
\hline & & & & $\mathbf{R}$ value \\
\hline Treatment time (months) & 32.2 & 14.06 & - & - \\
\hline Age at $T_{0}$ (years) & 27.7 & 9.95 & - & - \\
\hline Number of appliance issues/breakages & 3 & 5 & - & - \\
\hline Months of missed appointments & 3.08 & 2.02 & - & - \\
\hline Number of extractions & 0.75 & 1.41 & - & - \\
\hline PAR index at $T_{0}$ & 14.06 & 7.75 & 0.94 & 0.9662 \\
\hline
\end{tabular}

SD - Standard deviation

Table 3 - Correlation Matrix and linear regression analysis.

\begin{tabular}{|c|c|c|c|c|c|c|c|}
\hline \multirow{3}{*}{ Independent variables $(n=70)$} & \multicolumn{4}{|c|}{ Correlation matrix } & \multicolumn{3}{|c|}{ Linear regression } \\
\hline & & \multicolumn{3}{|c|}{ Multiple } & \multicolumn{3}{|c|}{ Stepwise } \\
\hline & & p value & $F$ & $R^{2}$ & p value & $\mathbf{R}^{2}$ & Variability $\mathbf{R}^{2}$ \\
\hline Number of issues/breakages & 0.9963 & $<0.0001$ & & & $<0.0001$ & $29.71 \%$ & $29.71 \%$ \\
\hline No-shows (months of missed appointments) & 0.9732 & $<0.0001$ & & & 0.0037 & $43.75 \%$ & $14.04 \%$ \\
\hline PAR index $\left(T_{0}\right)$ & 0.8474 & 0.0009 & & & 0.1689 & $50.26 \%$ & $6.51 \%$ \\
\hline Metal x Ceramic & 0.6903 & 0.005 & & & 0.1128 & $51.91 \%$ & $1.65 \%$ \\
\hline Number of extractions & 0.3443 & 0.0543 & 15.2284 & 0.5076 & 0.0698 & $54.33 \%$ & $2.42 \%$ \\
\hline Age at $T_{0}$ (years) & 0.0218 & 0.7737 & & & - & - & - \\
\hline Sex & 0.0409 & 0.4804 & & & - & - & - \\
\hline Class I vs. Class II & 0.1734 & 0.1645 & & & - & - & - \\
\hline Facial pattern at $T_{0}$ & 0.054 & 0.4275 & & & - & - & - \\
\hline
\end{tabular}




\section{DISCUSSION}

Today, establishing distinct goals as the desired outcomes of orthodontic treatment in adult patients is under debate. Thus, assessing the influence of some variables on treatment time is of paramount importance in defining the guidelines of orthodontic treatment in these patients. Some studies have examined factors related to treatment time. However, the mixed results achieved by these different studies - whose samples comprise adults, youth and children - have raised doubts as to the factors that may unequivocally have a bearing on the duration of orthodontic treatment in adults.

This study was therefore geared exclusively towards the study of adult patients treated by three seasoned professionals, each with over 20 years experience, thereby reinforcing and enhancing the reliability of the results. Furthermore, as a result, "lack of experience" is ruled out as a factor that could lengthen the duration of treatment.

The mean duration of treatment in this study was 32.2 months, similar to the findings of Dyer et al. ${ }^{3}$ (30.7 months) and Robb et al. ${ }^{7}$ (30.6 months).

The variables that showed statistically significant influence on treatment time were "number of months the case was left with no monitoring due to missed or canceled appointments" ( $p<0.0001)$, which accounted for $4.14 \%$ of the influence on the overall treatment time, and "number of appliance issues/breakages" ( $p=0.0037)$, with an influence of 29.71\%. These results corroborate previous findings. ${ }^{4,5,7,9,18,21}$ And although all these studies included adult patients in their samples, they also had children and/or adolescents, which shows that regardless of age, behavioral factors pertaining to the patients themselves can exert substantial influence on the duration of treatment.

Insofar as Class I or Class II relationship is concerned, this study was based on the canine relationship given that patients with missing teeth were also included. This contrasts with the studies found in the literature, which focus solely on molar relationship. Some studies found no influence of the molar relationship on treatment time. ${ }^{10}$ However, other studies ${ }^{9,11}$ reported that the treatment of patients who present with a Class II at the beginning of treatment seem to take longer than Class I patients. The study by Skid- more et al. ${ }^{9}$ may have been influenced by the decision to extract teeth when the treatment was already in an advanced stage as the patient failed to wear intraoral elastics. In turn, in the work of $\mathrm{Vu}$ et al. ${ }^{11}$ length of treatment may have been affected by the authors' decision to carry out treatment in two phases. In this study, the canine relationship was initially a variable that did not increase the duration of treatment significantly. It should be noted that in the present investigation $13.51 \%$ of patients started treatment with a Class II, and eventually had this relationship corrected only at the level of the canines by extracting two maxillary premolars. Given that these patients continued to present with molar Class II malocclusion, one might feel compelled to question the fact that if the molar sagittal relationship had also been corrected, treatment time may have been prolonged.

The variable "type of bracket", whether metal or ceramic, had no bearing on the duration of treatment. This factor has seldom been explored in the literature. It can only be found in a study by Beckwith et al, ${ }^{4}$ which concludes that it has no influence on the length of treatment.

The decision to extract or not to extract and the amount of extractions planned for orthodontic treatment has been a widely researched variable that helps to determine to what extent the total treatment time is affected by these extractions. This has been an ongoing concern of orthodontists. Although significant relationships between duration of treatment and the decision to extract, or not, have been widely observed in the literature, $5,6,8,9,15,16,18,19,20,21,23,24$ this study could not find a significant relationship between these variables, concluding that the decision to extract or not does not affect treatment time. This outcome resembles the findings of Beckwith et al, ${ }^{4}$ Poppwich et al, ${ }^{10}$ and Bhattarai et al. ${ }^{17}$

As documented in the literature, patient sex had no impact on the duration of treatment. ${ }^{4,5,8}$ One exception is the work of Skidmore et al, ${ }^{9}$ which found that male patients are a predictor of longer treatment time. The variable "facial pattern" had not been examined in previous studies in terms of orthodontic treatment time. It was assessed in this study and showed no such influence.

In assessing the severity of the initial malocclusion, as measured in this study through the PAR index, 
the authors believed that the patient's initial occlusal problems would likely lengthen treatment time, which might be necessary to tackle those issues satisfactorily. This variable, however, did not play a statistically significant role in the duration of treatment, corroborating previous findings. ${ }^{6,7,13}$ Nevertheless, other studies have revealed that the severity of the initial malocclusion influences to a significant extent the duration of treatment. ${ }^{5,8,11,12,14,15}$

It should be noted that all studies referenced in this research involved the investigation of variables likely to influence treatment time. None of them, however, focused exclusively on adult patients, but rather included children and/or adolescent patients in their sample. This realization underscores the importance of conducting further studies geared specifically to adult patients.

\section{REFERENCES}

1. Maltagliati LA, Montes LAP. Análise dos fatores que motivam os pacientes adultos a buscarem o tratamento ortodôntico. Rev Dental Press Ortod Ortop Facial. 2007:12(6):54-60

2. Capelloza Filho L, Braga AS, Cavassan AO, Ozawa TO. Tratamento ortodôntico em adultos: uma abordagem direcionada. Rev Dental Press Ortod Ortop Facial. 2001; 6(5):63-80

3. Dyer GS, Harris EF, Vaden JL. Age effects contrasted on orthodontic with adults treatment: Adolescents. Am J Orthod Dentofacial Orthop. 1991;100(6):523-30.

4. Beckwith FR, Ackerman RJ, Cobb CM, Tira DE. An evaluation of factors affecting duration of orthodontic Treatment. Am J Orthod Dentofacial Orthop. 1999:115(4):439-47.

5. Fink DF, Smith RJ. The duration of orthodontic treatment. Am J Orthod Dentofacial Orthop. 1992;102(1):45-51.

6. Mavreas D, Athanasiou AE. Factors affecting the duration of orthodontic treatment: a systematic review. Eur J Orthod. 2008:30(4):386-95.

7. Robb SI, Sadowsky C, Schneider BJ, Begole EA. Effectiveness and duration of orthodontic treatment in adults and adolescents. Am J Orthod Dentofacial Orthop. 1998;114(4):383-6.

8. Haralabakis NB, Tsiliagkou $K$. The effect of six variables and their interrelation on the duration of orthodontic treatment. Hellenic Orthod Rev. 2004;7(1):45-57.

9. Skidmore KJ, Brook KJ, Thomson WM. Harding WJ. Factors influencing treatment time in orthodontic patients. Am J Orthod Dentofacial Orthop. 2006:129(2):230-8.

10. Popowich K, Flores-Mir C, Nebbe B, Heo G, Major PW. Comparison of Class I and Class II treatment duration among three different orthodontic practices. Semin Orthod. 2006;12(1):52-9.

11. Vu CQ, Roberts WE, Hartsfield JK Jr, Ofner S. Treatment complexity index for assessing the relationship of treatment duration and outcomes in a graduate orthodontics clinic. Am J Orthod Dentofacial Orthop. 2008;133(1):9.e1-13.

\section{CONCLUSIONS}

Based on the findings of the study, the following conclusions can be drawn:

1. Patients' behavioral factors (missed appointments and appliance issues/breakages) played a significant part in lengthening treatment time.

2. Other factors such as initial canine relationship, the choice of metal or ceramic brackets, extractions included in the orthodontic plan, initial age, PAR index at the start of treatment, sex and facial pattern had no significant influence on the treatment time of adult patients.

3. Within the scope of this study it was found that these variables accounted for only $54.3 \%$ of the overall influence exerted on the duration of treatment, suggesting that other factors should be investigated to determine the actual time length required to perform orthodontic treatment in adults.
12. Dyken RA, Sadowsky PL, Hurst D. Orthodontic outcomes assessment using the peer assessment rating index. Angle Orthod. 2001;71(3):164-9.

13. Grewe JM, Hermanson PC. Influence of severity of malocclusion on the duration of orthodontic treatment. Am J Orthod. 1973;63(5):533-6.

14. Miguel JAM, Calheiros AA. A utilização do índice PAR no estudo da relação entre o tempo de tratamento com a severidade inicial e o grau de melhora da maloclusão. Rev Bras Odontol. 2013;60(3):208-12

15. Taylor PJS, Kerr WIS. Factors associated with the standard and duration of orthodontic treatment. Br J Orthod. 1996;23(4):335-41.

16. Alger DW. Appointment frequency versus treatment time. Am J Orthod Dentofacial Orthop. 1998:94(5):436-9

17. Bhattarai P. Shrestha RM, Mishra P. Comparison of duration of orthodontic treatment with and without extraction among orthodontic patients. J Nepal Dent Assoc. 2009;10(2):119-21.

18. De Saturno LD, Camardiel A. La duración del tratamiento ortodoncico y sus condicionantes. Acta Odontol Venez. 1999;37(1):17-29.

19. Fisher MA, Wenger RM, Hans MG. Pretreatment characteristics associated with orthodontic treatment duration. Am J Orthod Dentofacial Orthop. 2010;137(2):178-86

20. Janson G, Maria FR, Barros SE, Freitas MR, Henriques JF. Orthodontic treatment time in 2- and 4-premolar-extraction protocols. Am J Orthod Dentofacial Orthop. 2006:129(5):666-71

21. Maria FRT. Estudo do tempo de tratamento de casos tratados ortodonticamente com extrações de dois pré-molares superiores comparados aos de extrações de quatro pré-molares [dissertação] Bauru (SP): Universidade de São Paulo; 2003

22. Popowich K, Nebbe B, Heo G, Glover KE, Major PW. Predictors for Class II treatment duration. Am J Orthod Dentofacial Orthop. 2005:127(3):293-300.

23. Salazar RL. Avaliação do tempo e do grau de eficiência do tratamento da má oclusão de Classe I realizado com e sem extrações de prémolares [dissertação]. Bauru (SP): Universidade de São Paulo; 2008.

24. Vig PS, Weintraub JA, Brown C, Kowaiski CJ. The duration of orthodontic treatment with and without extractions: a pilot study of five selected practices. Am J Orthod Dentofacial Orthop. 1990;97(1):45-51. 